\title{
POSITIFIKASI HUKUM ISLAM DALAM HUKUM NASIONAL DALAM PRESPEKTIF FILSAFAT ILMU
}

\author{
Oleh: \\ M. Nur Kholis Al Amin \\ Universitas Cokroaminoto Yogyakarta
}

\begin{abstract}
Abstrak
Peraturan-peraturan hukum yang bersifat mengatur dan memaksa anggota masyarakat untuk patuh menaatinya, menyebabkan terdapatnya keseimbangan dalam tiap perhubungan dalam masyarakat.Hukum nasional memiliki legitimas di seluruh negeri dan dipaksakan keberlakuannya, di samping itu juga berlaku fiksi hukum. Oleh karena itu, masyarakat Indonesia yang notabene mayoritas muslim juga membutuhkan aturan yang mengatur tentang hubungan masyarakat muslim tersebut sebagaimana —akhir-akhir ini-yang tertuang pada UU No. 3 Tahun 2006 tentang Peradilan Agama, UU No. 1 Tahun 1974 tentang Perkawianan, Inpres No. 1 Tahun 1991 tentang Kompilasi Hukum Islam. Undang-undang sebagaimana di atas merupakan sebagian kecil hasil dari positifikasi hukum Islam ke dalam hukum Nasional, positifikasi hukum Islam tersebut apabila didekati dengan filsafat barat (sebagai acuan kebenaran ilmiah) maka dengan pendekatann ontology, epistemologi, dan aksiologi, sudah memenui ketiga unsur tersebut, dengan ontology yang melihat hakikat keberadaan hukum Islam yang pernah berlaku di Indonesia, epistemology yang menguraikan struktur keberlakuan hukum Islam yang telah menjadi hukum positif ataupun cara positifikasi hukum nasional, dan aksiologi yang menjelaskan kegunaan positifikasi hukum yang diantaranya mempunyai kegunaan sebagai kepastian hukum yang tidak terlepas dari landasan fiosofis, yuridis, dan sosiologis.
\end{abstract}

Kata Kunci: Hukum Islam, Hukum Nasional, Filsafat Ilmu

\section{Pendahuluan}

Sudah menjadi bagian dari retorika di negeri kita ini bahwa Islam adalah agama mayoritas.Retorika ini malah menyebutkan angka 90 sebagai presentasi kaum Muslim dari seluruh penduduk negeri, tanpa pernah dipersoalkan darimana asal-usul angka itu selain perkiraan dari kesan. ${ }^{3}$ Walaupun begitu Islam memang merupakan bagian agama terbesar di Negara Indonesia. Namun demikian, Indonesia bukan Negara Islam, akan tetapi Indonesia adalah

\footnotetext{
${ }^{3}$ Nurcholis Madjid, "Islam di Indonesia dan Potensinya Sebagai Sumber Ideologi dan Etos Nasional", dalam Islam Universal, (Yogyakarta: Pustaka Pelajar, 2007), hlm. 168.
} 
Negara yang berdasarkan atas hukum (rechtsstaat) dan tidak berdasarkan kekuasaan

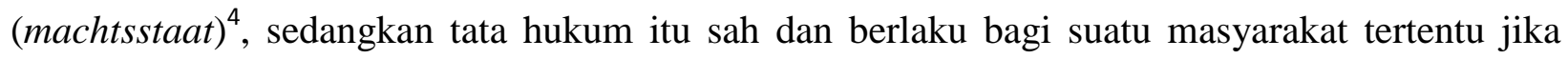
dibuat, ditetapkan oleh penguasa (authority) masyarakat itu ${ }^{5}$ yang biasa disebut dengan hukum positif (ius contitutum). Oleh karena itu, sudah menjadi ketentuan umum, bahwa setiap kelompok mayoritas akan menginginkan aturan yang khusus untuk mengatur keberadaannya. ${ }^{6}$ Dengan kata lain, umat Islam mengharapkan hukum Islam yang mengatur tentang mu'amalat bagi umat Islam diatur juga dalam hukum positif. Dengan demikian, menurut penulis, kiranya tema "Posifikasi Hukum Islam dalam Hukum Nasional Menurut Perspektif Filsafat Ilmu" menarik untuk dikaji mengingat akhir-akhir ini banyak usaha mempositifikasikan atau mengamandemen undang-undang yang mempunyai kandungan hukum Islam, sebagai contoh UU No. 3 Tahun 2006 tentang Peradilan Agama, yang tertuang didalamnya aturan-aturan tentan ekonomi syariah.

\section{Pentingnya Kaidah (Norma) Hukum}

Dalam masyarakat setiap anggota masyarakat mempunyai kepentingan.Kadang-kadang antara kepentingan satu anggota masyarakat dengan anggota masyarakat lainnya mempunyai persamaan.Akan tetapi, tidak jarang pula kepentingan antara mereka itu bertentangan.Dalam banyak peristiwa perbedaan kepentingan ini dapat menimbulkan perselisihan bahkan kekacauan. Oleh karena itu, untuk menghindari tejadinya pertentangan yang berakhir dengan kekacauan, maka masyarakat memerlukan adanya suatau tatanan (orde atau ordenung), yaitu berupa aturanaturan yang menjadi pedoman dan bimbingan segala tingkah laku manusia dalam pergaulan hidup bermasyarakat.Dengan adanya aturan tersebut, setiap anggota masyarakat diharapkan dapat melaksanakan kepentingannya secara tentram dan damai.Setiap masyarakat dapat mematuhi dan mentaati hak dan kewajibannya masing-masing. Tata (orde atau ordenung) tersebut di atas dalam kajian ilmu hukum dikenal dengan kaidah atau norma. ${ }^{7}$ Namun, disini penulis tidak akan merinci secara detail macam-macam kaidah yang berlaku di Indonesia, akan

\footnotetext{
${ }^{4}$ Siti Fatimah, Praktik Judicial Riview di Indonesia,(Yogyakarta: Pilar Media, 2005), hlm. 34. Baca juga dalam Padmo Wahjono, "Indonesia Negara Berdasarkan Atas Hukum”, (Jakarta: Ghalia Indonesia, 1986), hlm. 73.

${ }^{5}$ CST.Kansil, Pengantar Hukum dan Tata Hukum Indonesia, (Jakarta: Balai Pustaka, 1989).Hlm 169.

${ }^{6}$ Bisa dilihat dalam perjalanan panjang lahirnya UU Perkawinan.

${ }^{7}$ Hasanuddin Af, dkk, Pengantar Ilmu Hukum, (Jakarta: Pustaka Al Husna Baru \& UIN Jakarta Press: 2004), hlm. 30.
} 
tetapi penulis hanya akan menjabarkan kaidah hukum secara umum. Peraturan-peraturan hukum yang bersifat mengatur dan memaksa anggota masyarakat untuk patuh menaatinya, menyebabkan terdapatnya keseimbangan dalam tiap perhubungan dalam masyarakat. Setiap hubungan kemasyarakatan tak boleh bertentangan dengan ketentuan dalam peraturan hukum yang ada dan berlaku dalam masyarakat.

Setiap pelanggar peraturan hukum yang ada, akan dikenakan sanksi yang berupa hukuman sebagai reaksi terhadap perbuatan yang melanggar hukum yang dilakukannya. ${ }^{8}$ Dengan kata lain, peraturan yang timbul dari norma hukum, dibuat oleh penguasa Negara. Isinya mengikat setiap orang dan pelaksanaannya dapat dipertahankan dengan segala paksaan oleh alatalat Negara.Oleh karena itu, masyarakat yang beragam ini sangat penting diikat dengan aturan hukum yang mempunyai sanksi yang tegas.

\section{Ciri-ciri Negara Hukum dan Hukum Nasional}

Negara sebagai wujud implementasi dari suatu kontrak social dalam penyelenggaraannya senantiasa membutuhkan suatu instrument tersendiri yang spesifik, independen, serta terjamin pelaksanaan aspek-aspek fungsionalnya, dan diantaranya yang paling pokok yakni hukum. ${ }^{9}$ Adapun ciri dari Negara hukum menurut Frederich Julius Stah—sebagaimana yang dikutip Siti Fatimah—adalah:

1. Mengakui dan melindungi HAM

2. Penyelenggaraan Negara berdasarkan trias politika

3. Pemerintahan berdasarkan atas UU

4. Peradilan Administrasi. ${ }^{10}$

Indonesia yang merupakan Negara hukum, maka dalam pelaksanaan ketertiban aturanaturannya juga dengan hukum yang berlaku di Indonesia yang biasa kita kenal dengan hukum nasional. Hukum nasional ini memiliki sekalian kelengkapan untuk bias dijalankan secara efektif, mulai dari teks tertulis, aparat penegak hukum, dukungan finansial dan kelengkapan fisik

${ }^{8}$ CST.Kansil, Pengantar Hukum dan Tata Hukum Indonesia, (Jakarta: Balai Pustaka, 1989).Hlm 40.

${ }^{9}$ Hasanuddin Af, dkk, Pengantar Ilmu Hukum, (Jakarta: Pustaka Al Husna Baru \& UIN Jakarta Press: 2004), hlm. 169.

${ }^{10}$ Siti Fatimah, dalam Kuliah Hukum Tata Negara, Fakultas Syariah, 2008 
lainnya. Hukum nasional memiliki legitimas di seluruh negeri dan dipaksakan keberlakuannya.Rakyat harus mematuhi hukum nasional tersebut. ${ }^{11}$ Dengan melihat kenyataan di atas, maka penulis mencoba menelaah ulang tentang keberadaan "hukum Islam" agar dapat memposisikan dirinya pada masyarakat Indonesia yang notabene mayoritas pemeluk agama Islam, untuk itu, kiranya menarik ketika mencoba menelaah positifikasi hukum Islam dalam Hukum nasional menurut perspektif Filsafat Ilmu.

\section{Positifikasi hukum Islam dalam Hukum Nasional: Kajian Filsafat.}

Filsafat merupakan suatu proses kritik atau pemikiran terhadap kepercayaan dan sikap yang sangat kita junjung tinggi, yakni usaha untuk mencari suatu kebenaran. Berpijak pada asumsi kebenaran adalah apa yang bisa diterima oleh akal, konsekuensinya, pencarian kebenaran haruslah berlangsung menurut prosedur-prosedur atau hukum-hukum yang mengkaidahi bekerjanya akal. Inilah yang disebut dengan logika.Logika merupakan hukum-hukum untuk berfikir tepat.Logika menggariskan kaidah-kaidah untuk berfikir tepat.Ia mempelajari syaratsyarat yang harus dipenuhi oleh pemikiran untuk membentuk pengetahuan yang tepat. ${ }^{12}$ Oleh karena itu, kiranya penting suatu telaah sains harus memenuhi unsur-unsur ontologi, epistimologi dan aksiologi ilmu tersebut, yang dalam hal ini adalah positifikasi hukum Islam dalam hukum nasional.

\section{Ontologi}

Dalam filsafat, ontologi membahas tentang yang ada, yang tidak terikat oleh suatu perwujudan tertentu.Ontologi membahas yang ada yang universal, menampilkan pemikiran semesta universal. Ontologi berupaya mencari inti yang termuat dalam setiap kenyataan, atau dalam rumusan Lorens Bagus: menjelaskan yang ada yang meliputi semua realitas dalam semua bentuknya. ${ }^{13}$ Dengan pernyataan tersebut, penulismengkorelasikan bahwaontologi terhadap positivikasi hukum Islam tidak mengesampingkan sejarah tentang hukum yang pernah berlaku di Indonesia. Secara garis besarnya, sistem hukum di Indonesia meliputi tiga macam; sistem hukum Adat, sistem hukum Islam, dan sistem hukum Barat. Dalam perkembangan sistem hukum di

\footnotetext{
${ }^{11}$ Satjipto Rahardjo, Biarkan Hukum Mengalir, Catatan Kritis Tentang Pergulatan Manusia dan Hukum, (Jakarta: Kompas, 2008), hlm. 58-59.

${ }^{12}$ Bambang sunggono, Metodologi Penelitian Hukum, (Jakarta: PT RajaGrafindo Persada, 2007), hlm. 8-9.

${ }^{13}$ Noeng Muhadjir, Filsafat Ilmu, Kualitatif dan Kuantitatif, ed. ke-3, (Yogyakarta: Rake Sarasin, 2006), hlm. 55.
} 
Indonesia di kemudian hari, ketiga sistem hukum dalam pengertiannya yang dinamis itu akan menjadi bahan baku hukum nasional. ${ }^{14}$ Memang, harus kita akui bahwa Indonesia setelah merdeka lebih dari setengah abad belum mempunyai undang-undang yang menyeluruh yang berisi hukum nasional yang memang produk bangsa kita sendiri.Undang-undang yang ada masih berupa peninggalan Belanda dengan beberapa tambal sulam produk lembaga legislatif kita secara ad hoc. ${ }^{15}$ Indonesia yang merupakan Negara hukum, maka peraturan perundang-undangannya dengan sistem hukum yang berlaku di Indonesia, yakni dikodifikasi dalam bahasa hukum formal. ${ }^{16}$ Jadi, keberadaan hukum Islam di Indonesia akan lebih terasa ketika asas-asas hukum Islam yang ditampilkan dalam bahasa keagamaan fikih dikodifikasi dalam bahasa hukum. ${ }^{17}$ Dengan demikian, salah satu upaya positifikasi hukum Islam (seperti UU No. 1 Tahun 1974 Tentang Perkawinan, UU. No 3 Tahun 2004 Tentang Peradilan Agama, Inpres No. 1 Tahun 1991; KHI)akan terealisasi, yang pada akhirnya hukum Nasional tidak menafikansistem hukum Islam pernahberlaku di Indonesia.Di samping itu, hakikat keberadaan hukum Islam yang telah dikodifikasi sebagai hukum positif merupakan salah satu bagian dari hukum nasional.

\section{Epistemologi}

Epistemologi ilmu meliputi sumber, sarana, dan tatacara menggunakan sarana tersebut untuk mencapai pengetahuan (ilmiah). Perbedaan mengenai pilihan landasan ontologik akan sarana yang akan kita pilih. Akal (verstand), akal budi (vernunft) pengalaman, atau kombinasi antara akal dan pengalaman, intuisi, merupakan sarana yang dimaksud dalam epistimologik, sehingga dikenal adanya model-model epistemologik seperti: rasionalisme, empirisme, kritisisme atau rasionalisme kritis, positivisme, fenomenologi dengan berbagai variasinya. ${ }^{18}$ Dengan bentuk-bentuk pemahaman epistemologi, seperti dengan model epistemologik fenomenologi dengan berbagai variasinya, merupakan kerangka berfikir dan analisis terhadap positifikasi hukum Islam dalam hukum nasional sebagaimana berikut.

\footnotetext{
${ }^{14}$ A. Qodri Azizy, Eklektisisme Hukum Nasional; Kompetisi Antara Hukum Islam dan Hukum Umum, cet. ke-4, (Yogyakarta: Gama Media, 2004), hlm. 111.

${ }^{15}$ Ibid., 114.

${ }^{16}$ Bahasa hukum formal yang dimaksud sebagaimana bahasa yang terdapat dalam undang-undang ataupun perudangundangan di Indonesia yang salah satu cirinya adalah bahasanya dengan pasal-pasal, contoh: KUHP, KUHAP, UU No. 1 Tahun 1974 Tentang Perkawinan, dll.

${ }^{17}$ Baca dalam, Syamsul Anwar, "Studi Hukum Islam Kontemporer", (Jakarta: RM Books, 2007), hlm. 2007.

${ }^{18}$ Tim Dosen Filsafat Ilmu, Filsafat Ilmu, Sebagai Dasar Pengembangan Ilmu Pengetahuan, (Yogykarta: Liberty, 2003), hlm. 12.
} 
Semenjak proklamasi kemerdekaan, pembinaan hukum Nasional haruslah berdasarkan falsafah Negara Pancasila.Konsep Negara hukum pancasila (hukum nasional) meletakkan pancasila sebagai sumber dari segala sumber yang berlaku di Negara Republik Indonesia. Pancasila yang kita gali dari bumi Indonesia sendiri ini merupakan:

1) Dasar Negara kita

2) Sumber dari segala sumber hukum yang berlaku di Negara kita

3) Pandangan hidup bangsa Indonesia yang dapat mempersatukan bangsa

4) Jiwa dan kepribadian bangsa Indonesia

5) Hasil budidaya bangsa Indonesia, yakni merupakan kebudayaan bangsa Indonesia. ${ }^{19}$

Falsafah Negara hukum pancasila tersebut dalam pembinaan Negara hukum mempunyai sistematika peraturan perundang-undangan yang berlaku di Negara Indonesia yang biasa disebut dengan hirarki peraturan perundang-undangan. Adapun bentuk hirarki peraturan perundangundangan:

1) Undang-undang Dasar 1945.

2) Ketetapan Majelis Permusyawaratan Rakyat Indonesia.

3) Undang-undang.

4) Peraturan Pemerintah Pengganti Undang-undang.

5) Peraturan Pemerintah.

6) Keputusan Presiden.

7) Peraturan Daerah. ${ }^{20}$

Jadi, secara epistemology atau sumber, struktur dan sahnya hukum Islam dalam ranah hukum nasional akan diakui ketika sudah dipositifikasikan dalam salah satu bentuk hirarki di atas, sebagaimana UU No. 1/1974 Tentang Perkawinan, UU No.7/1989 tentang Peradilan Agama. Dengan demikian, positifikasi hukum Islam dalam hukum Nasional mempunyai dasar untuk bisa diterima oleh masyarakat Indonesia, khususnya masyarakat muslim.

\section{Aksiologi}

${ }^{19}$ Sjechu Hadi Permono, Peran Hukum Islam dalam Upaya Supremasi Hukum di Indonesia, dalamAULA , 2000, hlm. 73.

${ }^{20}$ Ruchiyatun, Materi Kuliah Legal Drafting, 2009.Lihat pula dalam Bambang Sunggono "Metode Penelitian Hukum", hlm. 94. Yang membagi dalam tiga pengklasifikasian yakni (1). UUD 1945, (2).Ketetapan MPR (S) yang meliputi; UU/ Perpu, PP, Kepres, dan (3).Peraturan-peraturan Pelaksana lainnya; Peraturan Menteri, Instruksi Menteri, dan lainnya.Lihat pula dalam Pasal 7 UU No. 10 Tahun 2004. 
Aksiologi merupakan cabang filsafat yang mempelajari kegunaan ilmu, dalam hubungannya dengan pembahasan tulisan ini, maka kegunaan positifikasi hukum Islam tidak lain adalah untuk kepastian hukum yang berdasarkan pada tata hukum nasional yang baik. Tata hukum nasional yang baik, adalah hukum yang berlandaskan akan tiga hal dasar, yakni:

1) Landasan Filosofis. Landasan ini dapat ditemukan pada sumber dasar hukum, yakni ideologi bangsa Indonesia (Pancasila), dan cita-cita hukum nasional (ketertiban, keamanan dan keadilan).

2) Landasan Yuridis. Landasan ini dapat ditemukan pada pertingkatan hukum nasional, mekanisme pengembangan hukum nasional dan lembaga yang menangani hukum nasional.Jadi, landasan yuridis ini adalah landasan yang menuntut adanya persyaratan formal, tidak bertentangan (sesuai) dengan aturan yang berlaku di Indonesia secara sah.

3) Landasan Sosiologis. Landasan sosiologis merupakan landasan yang harus memperhatikan nilai yang diterapkan dan diterima oleh masyarakat. ${ }^{21}$

Dengan demikian, positikasi hukum Islam dalam hukum Nasional haruslah mempertimbangkan tiga aspek tersebut agar tujuan dari positifikasi hukum Islam dapat berguna untuk mengatur masyarakat muslim Indonesia dan mempunyai tujuan yang jelas, yakni adanya kepastian hukum.

\section{Penutup}

Masyarakat memerlukan adanya suatau tatanan (orde atau ordenung), yaitu berupa aturan-aturan yang menjadi pedoman dan bimbingan segala tingkah laku manusia dalam pergaulan hidup bermasyarakat. Peraturan-peraturan hukum yang bersifat mengatur dan memaksa anggota masyarakat untuk patuh menaatinya, menyebabkan terdapatnya keseimbangan dalam tiap perhubungan dalam masyarakat.Hukum nasional memiliki legitimas di seluruh negeri dan dipaksakan keberlakuannya, di samping itu juga berlaku fiksi hukum. Oleh karena itu, masyarakat Indonesia yang notabene mayoritas muslim juga membutuhkan aturan yang mengatur tentang hubungan masyarakat muslim tersebut sebagaimana-akhir-akhir ini-yang tertuang pada UU No. 3 Tahun 2006 tentang Peradilan Agama, UU No. 1 Tahun 1974 tentang Perkawianan, Inpres No. 1 Tahun 1991 tentang Kompilasi Hukum Islam.

\footnotetext{
${ }^{21}$ M. Nur Kholis Al Amin, makalah Harmonisasi Peraturan Perundang-Undangan, 2009, hlm. 3.
} 


\section{Daftar Pustaka}

Anwar, Syamsul,Studi Hukum Islam Kontemporer, Jakarta: RM Books, 2007.

Al Amin, M. Nur Kholis, makalah Harmonisasi Peraturan Perundang-Undangan, 2009.

Azizy, A. Qodri,Eklektisisme Hukum Nasional; Kompetisi Antara Hukum Islam dan Hukum Umum, cet. ke-4, Yogyakarta: Gama Media, 2004

CST. Kansil, Pengantar Hukum dan Tata Hukum Indonesia, Jakarta: Balai Pustaka, 1989

Fatimah, Siti, Praktik Judicial Riview di Indonesia, Yogyakarta: Pilar Media, 2005

Hasanuddin Af, dkk, Pengantar Ilmu Hukum, Jakarta: Pustaka Al Husna Baru \& UIN Jakarta Press: 2004

Madjid,Nurcholis, "Islam di Indonesia dan Potensinya Sebagai Sumber Ideologi dan Etos Nasional”, dalam Islam Universal, Yogyakarta: Pustaka Pelajar, 2007

Muhadjir, Noeng,Filsafat Ilmu, Kualitatif dan Kuantitatif, ed. ke-3, Yogyakarta: Rake Sarasin, 2006

Permono, Sjechu Hadi,Peran Hukum Islam dalam Upaya Supremasi Hukum di Indonesia, dalamAULA , 2000.

Rahardjo, Satjipto,Biarkan Hukum Mengalir, Catatan Kritis Tentang Pergulatan Manusia dan Hukum, Jakarta: Kompas, 2008

Sunggono, Bambang, Metodologi Penelitian Hukum,Jakarta: PT RajaGrafindo Persada, 2007

Tim Dosen Filsafat Ilmu, Filsafat Ilmu, Sebagai Dasar Pengembangan Ilmu Pengetahuan, Yogyakarta: Liberty, 2003.

Wahjono,Padmo, "Indonesia Negara Berdasarkan Atas Hukum", Jakarta: Ghalia Indonesia, 1986 